\title{
Effect of soybean feeding on productivity of sows, growth of piglets and quality of pork
}

\author{
V.V. Tedtova ${ }^{1}$, R.B. Temiraev ${ }^{1}$, V.R. Kairov ${ }^{2 \& 3}$, A.S. Dzhaboeva ${ }^{1}$, N. A. \\ Yurina $^{4 \& 5}$, K.B. Temiraev ${ }^{1}$, Z.T. Baeva ${ }^{1}$, L.A. Bobyleva ${ }^{6}$, E.F. \\ Zagaraeva $^{6}$, B.S. Efendiev ${ }^{7}$
}

\begin{abstract}
${ }^{1}$ North-Caucasian Mining and Metallurgical Institute (State Technological University), Vladikavkaz 362021; ${ }^{2}$ Gorsky State Agrarian University, 362040, Vladikavkaz, 37 Kirov Street; ${ }^{3}$ North Caucasian Research Institute of Mountain and Piedmont Agriculture - the Affiliate of Vladikavkaz Scientific Centre of the Russian Academy of Science, 363110, 1 Williams Str., Mihkailovskoe vil., Republic of North Ossetia - Alania; ${ }^{4}$ Krasnodar Research Centre for Animal Husbandry and Veterinary Medicine, Krasnodar 350055; ${ }^{5}$ Kuban State Agrarian University named after I.T. Trubilina, Krasnodar 350044; ${ }^{6}$ North-Ossetian State University named after K.L. Khetagurov, Vladikavkaz, 362025; Kabardino-Balkarian State Agrarian University named after Kokov, Nalchik, 360030, Russian Federation.
\end{abstract}

Journal of Livestock Science (ISSN online 2277-6214) 11:20-25

Received on 1/11/2019; Accepted on 10/1/2020

doi. 10.33259/JLivestSci.2020.20-25

\begin{abstract}
One of the sources of high-grade vegetable protein is soybean, subjected to various methods of moisture and heat treatment. Its introduction into diets practically solves the problems of providing animals with essential amino acids. Therefore, the study of biological and productive characteristics and the quality of meat of young pigs under the influence of different levels of soy protein from non-genetically modified soybean variety was an actual problem. The aim of the research is to study the effect of feeding different doses of non-genetically modified soybean on the biological and productive parameters of pigs and the consumer characteristics of pork. Young fattening pigs and sows of the Large white breed were the object of the research. To study the effect of different doses of the soybean (15.25 and 35\% of the rate of digestible protein), 4 groups of pigs were formed. The soybean of the non-genetically modified "Early-10" variety was subjected to a moisture and thermal treatment in a microwave unit for inactivation of anti-nutrients. The most positive effect on the productivity and reproductive characteristics of sows was provided by soy addition in a dose of $25 \%$ of the rate of digestible protein. Compared to the control group, the gilts of the $2^{\text {nd }}$ experimental group had significantly $(\mathrm{P}<0.05)$ better indicators of pre-slaughter live weight by $12.02 \mathrm{~kg}$, slaughter weight - by $10.74 \mathrm{~kg}$, slaughter yield - by $1.48 \%$, weight of chilled carcass - by $9.70 \mathrm{~kg}$, carcass yield - by $2.14 \%$, and weight of the posterior third of the side - by $1.01 \mathrm{~kg}$. The best indicators of the chemical composition showed the samples of the longissimus spinal muscle of the gilts of the $2^{\text {nd }}$ experimental group, significantly $(\mathrm{P}<0.05)$ exceeding the control in the dry matter content by $0.72 \%$, protein by $0.8 \%$, protein quality indicator (PQI) $-6.6 \%$.
\end{abstract}

Key words: non-genetically modified soybean; essential amino acids; sows; fattening young pigs; consumer qualities of pork; biological value of meat. 


\section{Introduction}

Protein supply of diets for pigs is important for the increase of the consumer qualities of pork. At the present time, the growth in the productivity of pigs and the improvement in the quality of products are hampered by the lack of protein in diets, the deficiency of which is about 30-35\% of the animal's requirement (Khamitsayeva et al., 2009; Temirayev et al., 2009).

One of the sources of complete vegetable protein is soybean and products of its processing, subjected to various methods of moisture-heat treatment. Their introduction into diets practically solves the problems of providing animals with essential amino acids (Temirayev et al., 2009). However, given the fact that soy products deteriorate the quality of pig meat because of the high content of fat and the specific smell, the opinions of scientists and practitioners differ in the level of soy protein in feeding pigs. Soy products at the rate of 35-40\% of the digestible protein of the diet can serve as the only source of protein for young fattening pigs (Mamukayev et al., 2007). The amino acid composition and nutritional value of soy products have different effect on the growth of young pigs, since there are correlations between the content of total nitrogen in soybean and the amount of nonessential and essential amino acids (Temirayev et al., 2008; Kastuyev et al., 2007).

Considering the lack of sulfur-containing amino acids in soy products, the study of biological and productive indices and the quality of the meat of young pigs under the influence of different levels of soy protein from non-genetically modified soybean variety was an actual problem.

The aim of the present work is to study the effect of feeding different doses of non-genetically modified soybean on the biological and productive parameters of pigs and the consumer qualities of pork.

\section{Material and methods}

The experimental part of the work was carried out under the conditions of the "Vesna" agricultural production cooperative in the Digor district of RNO-Alania (Longitude: $44^{\circ} 40^{\prime} 04$ " East, Latitude: $43^{\circ} 02^{\prime} 12^{\prime \prime}$ North. Altitude: $671 \mathrm{~m}$ ). Young fattening pigs and sows of the Large white breed were the object of the research. Four groups of 4 heads each were formed immediately after the first mating from 16 brood sows at the age of 10-11 months to study the effect of different doses of soy protein on the growth of young animals, starting from the embryonic period of development.

In accordance with the scheme of the scientific and economic experiment (Table 1), 48 weaning pigs at the age of 2 months were selected out of the piglets from the sows. Four groups of 12 heads each were formed out of them according to the principle of pair- analogues, taking into account the live weight, age and sex. Daily diets for feeding gilts of the compared groups are shown in table 2 .

To have the fattening population, the preliminary replacement pigs when reached $130 \mathrm{~kg}$ of live weight were serviced, then they were transferred to the department for brood sows. The reproductive qualities of pigs were determined according to the generally accepted method. After the pigs reached the age of two months, taking into account their growth energy, according to the above scheme, 4 groups of young fattening pigs were formed.

Feeding of experimental animals was carried out twice a day. In carrying out the scientific and economic experiment, the gilts of all groups received the enzyme preparation of protosubtilin G3x at the rate of $0.03 \%$ of the dry weight of the ration.

Soybean of the non-genetically modified "Early-10" variety was excluded from the rations of fattening gilts of the experimental groups a month before the slaughter. This product was subjected to microwave treatment before feeding. The duration of fattening of the experimental animals was 150 days. For this purpose, 3 typical animals were selected from each group, which, according to conventional methods, were subjected to control slaughter.

Physico-chemical and technological properties of pig meat were investigated in the laboratory of agroecology of the Gorsky State Agrarian University, Russian Federation). The results obtained in the course of the scientific and economic experiment were processed statistically.

Table 1 - Scheme of scientific and economic experiment

\begin{tabular}{|l|l|l|l|}
\hline Group & $\begin{array}{l}\text { Number of } \\
\text { animals, heads }\end{array}$ & Ration characteristics & $\begin{array}{l}\text { Soybean dose, \% } \\
\text { digestible protein } \\
\text { rate }\end{array}$ \\
\hline Control & 12 & Basicdiet (BD) & - \\
\hline 1 trial & 12 & $85 \%$ BD of digestible proteinrate & 15 \\
\hline 2 trial & 12 & $\begin{array}{l}75 \% \text { BD of digestible protein } \\
\text { rate }\end{array}$ & 25 \\
\hline 3 trial & 12 & $65 \%$ BD of digestible proteinrate & 35 \\
\hline
\end{tabular}


Table 2 - Daily rations for gilts at the age of 5 - 6 months

\begin{tabular}{|l|c|c|c|l|}
\hline \multirow{2}{*}{ Indicators } & \multicolumn{4}{|c|}{ Groups } \\
\cline { 2 - 5 } & Control & 1 trial & 2 trial & 3 trial \\
\hline $\begin{array}{l}\text { Green mass of } \\
\text { alfalfa. kg }\end{array}$ & 1.6 & 1.6 & 1.6 & 1.6 \\
\hline Barda, kg & 5.0 & 5.0 & 5.0 & 5.0 \\
\hline Corn sack, kg & 1.24 & 1.40 & 1.30 & 1.00 \\
\hline Barley dart, kg & 0.1 & - & - & 0.4 \\
\hline Sunflower cake, & 0.10 & 0.19 & 0.10 & - \\
\hline Dry return kg & 0.2 & - & - & - \\
\hline Soybean, $\mathrm{k} \Gamma$ & - & 0.21 & 0.31 & 0.31 \\
\hline Table salt, g & 12 & 12 & 12 & 12 \\
\hline Protosubtilin G3X, & 0.21 & 0.21 & 0.21 & 0.21 \\
\hline Premix, g & 24 & 24 & 24 & 24 \\
\hline The diet contains:: & & & & \\
\hline Metabolic energy, & 27.10 & 27.45 & 25.20 & 27.10 \\
\hline Dry matter, kg & 2.08 & 2.14 & 2.05 & 2.10 \\
\hline Crude protein, g & 363.3 & 367.9 & 360.2 & 380.1 \\
\hline Digestible protein, & 283.0 & 287.8 & 282.1 & 294.2 \\
\hline Lysine, g & 15.2 & 13.5 & 14.4 & 16.3 \\
\hline Methionine + & 9.3 & 9.3 & 9.3 & 9.3 \\
\hline Crude fiber, g & 174.8 & 203.6 & 192.1 & 197.8 \\
\hline Calcium, g & 21.21 & 21.30 & 21.30 & 21.23 \\
\hline Phosphorus, g & 15.92 & 16.80 & 17.02 & 16.32 \\
\hline Iron, mg & 269.9 & 271.9 & 279.6 & 257.3 \\
\hline Copper, mg & 25 & 24.1 & 25.5 & 26.9 \\
\hline Zinc, mg & 124.0 & 124.64 & 125.3 & 122.0 \\
\hline Carotene, mg & 64.0 & $64 . .2$ & 64.0 & 64.0 \\
\hline
\end{tabular}

\section{Results and discussion}

The soybean of the non-genetically modified "Rannyaya-10" variety was subjected to moisture-thermal treatment in the "Slavyanka" microwave unit for inactivation of anti-nutrients in the mode: operating frequency $433 \mathrm{MHz}$, the smallest power $-2.5 \mathrm{~kW}$, the working chamber volume $-0.25 \mathrm{~m}^{3}$, processing time $-4 \mathrm{~min}$.

During the processing, the urease activity decreased from $0.74 \mathrm{pH}$ units at the beginning to 0.07 units, that is, 10.5 times. The content of trypsin inhibitor in soybean oil cake decreased by 12.5 times after processing and reached $0.10 \mathrm{~g} / \mathrm{kg}$ of product, which is within the maximum permissible level.

Soybean products are deficient in sulfur-containing amino acids, so synthetic methionine was added to the rations ofpigs in experimental groups to the feeding standards of methionine+cystine. The rations of fattening pigs should contain $0.950 \%$ of lysine and $0.455 \%$ of methionine + cystine, that is, their optimal ratio should be 1: 0.50 0.53 (Viktorov, 2003; Kononenko et al., 2014). Based on this, we calculated the ratio of some essential amino acids to each other (Table 3 ).

It was found that with the addition of soybean in the diets of gilts of the $2^{\text {nd }}$ experimental group, the ratio of lysine:methionine + cystine (1:0.50) and methionine: cystine (1: 0.33$)$ has been improved. When feeding soybean in doses of 15 and $35 \%$ of the rate of the digestible protein, this ratio was broken, that could have a negative effect on the productivity of the pigs.

When the live weight of pigs reached $130 \mathrm{~kg}$, they were serviced. After that, the diets of the pregnant sows from the experimental groups included different doses of soybean and we observed changes in their live weight.

Due to optimization of the ratio of lysine to methionine + cystine and methionine to cystine with the help of synthetic methionine additives, by the end of the gestation period, the animals of the 2 experimental group significantly $(\mathrm{P}<0.05)$ exceeded the control group's analogues in live weight by $10.21 \%$.

When soybean is included at the rate of $25 \%$, along with the improvement in the ratio of essential amino acids, the fiber level in the diet was $14 \%$ in dry matter, which had a beneficial effect on the productivity of the experimental sows (Table 4). 
Table 3 - Ratio of some essential amino acids in rations for young pigs

\begin{tabular}{|l|l|l|}
\hline Group & $\begin{array}{l}\text { lysine }: \\
\text { methionine }+ \text { cystine }\end{array}$ & $\begin{array}{l}\text { methionine } \\
\text { cystine }\end{array}$ \\
\hline Control & $1: 0.62$ & $1: 0.48$ \\
\hline 1 trial & $1: 0.56$ & $1: 0.41$ \\
\hline 2 trial & $1: 0.50$ & $1: 0.33$ \\
\hline 3 trial & $1: 0.44$ & $1: 0.25$ \\
\hline
\end{tabular}

Table 4 - Productivity and reproductive performance of sows

\begin{tabular}{|l|c|c|c|c|}
\hline \multirow{2}{*}{ Indices } & \multicolumn{3}{c|}{ Groups } \\
\cline { 2 - 5 } & control & 1 trial & 2 trial & 3 trial \\
\hline Multi parity,heads & $10.0 \pm 0.25$ & $10.5 \pm 0.23$ & $11.0 \pm 0.26$ & $10.7 \pm 0.17$ \\
\hline$\%$ to control & 100.0 & 105.0 & 110.0 & 107.0 \\
\hline $\begin{array}{l}\text { Weight per piglet, kg: } \\
\text { at birth }\end{array}$ & $1.17 \pm 0.005$ & $1.19 \pm 0.003$ & $1.21 \pm 0.004$ & $1.20 \pm 0.005$ \\
\hline 21 days old & $4.57 \pm 0.02$ & $4.68 \pm 0.02$ & $4.82 \pm 0.04$ & $4.74 \pm 0.03$ \\
\hline 60 days old & $17.57 \pm 0.22$ & $18.45 \pm 0.26$ & $18.79 \pm 0.29$ & $18.64 \pm 0.31$ \\
\hline Survival rate by weaning, \% & 90.5 & 91.4 & 92.0 & 91.7 \\
\hline Weight of piglets at birth, $\mathrm{kg}$ & $11.70 \pm 0.19$ & $12.49+0.23$ & $13.31+0.25$ & $12.84+0.20$ \\
\hline $\begin{array}{l}\text { Milkiness of sows on } 21^{\text {st }} \text { day after } \\
\text { birth, kg }\end{array}$ & $44.78 \pm 1.74$ & $47.88 \pm 1.79$ & $51.68 \pm 1.63$ & $49.64 \pm 1.68$ \\
\hline$\%$ to control & 100.0 & 106.9 & 115.4 & 110.8 \\
\hline Live wt gain for 2 months, $\mathrm{kg}$ & $16.40 \pm 0.23$ & $17.26 \pm 0.28$ & $17.58 \pm 0.36$ & $17.44 \pm 0.33$ \\
\hline$\%$ to control & 100.0 & 105.2 & 107.2 & 106.3 \\
\hline
\end{tabular}

Table 5 - Slaughter characteristics of experimental gilts

\begin{tabular}{|l|l|l|l|l|}
\hline \multirow{2}{*}{ Index } & \multicolumn{4}{c|}{ Group } \\
\cline { 2 - 5 } & Control & 1 trial & 2 trial & 3 trial \\
\hline Preslaughter live weight, $\mathrm{kg}$ & $102.70 \pm 1.3$ & $110.37 \pm 1.5$ & $114.72 \pm 1.4$ & $112.30 \pm 1.3$ \\
\hline Slaughter weight, kg & $77.24 \pm 1.5$ & $83.83 \pm 1.4$ & $87.98 \pm 1.1$ & $85.51 \pm 1.5$ \\
\hline Slaughter yield, \% & 75.21 & 75.95 & 76.69 & 76.15 \\
\hline Chilled carcass weight, kg & $61.95 \pm 1.2$ & $67.71 \pm 1.1$ & $71.65 \pm 0.9$ & $69.22 \pm 1.2$ \\
\hline Carcass yield, \% & 60.32 & 61.35 & 62.46 & 61.64 \\
\hline Carcass length, cm & $97.67 \pm 0.2$ & $100.77 \pm 0.3$ & $102.88 \pm 0.4$ & $101.51 \pm 0.4$ \\
\hline $\begin{array}{l}\text { Weight of the posterior third } \\
\text { of the carcass side, kg }\end{array}$ & $10.21 \pm 0.12$ & $11.08 \pm 0.14$ & $11.68 \pm 0.13$ & $11.22 \pm 0.13$ \\
\hline $\begin{array}{l}\text { Area of the "eye of meat", } \\
\mathrm{cm}^{2}\end{array}$ & $29.35 \pm 0.17$ & $30.36 \pm 0.2$ & $31.44 \pm 0.18$ & $30.75 \pm 0.24$ \\
\hline
\end{tabular}

Table 6 - Chemical composition and biological value of meat protein in gilts

\begin{tabular}{|l|l|l|l|l|}
\hline \multirow{2}{*}{ Index } & \multicolumn{4}{|c|}{ Group } \\
\cline { 2 - 5 } & control & 1 trial & 2 trial & 3 trial \\
\hline Dry matter, \% & $26.94 \pm 0.10$ & $27.37 \pm 0.12$ & $27.66 \pm 0.14$ & $27.19 \pm 0.19$ \\
\hline Protein, \% & $21,02 \pm 0.09$ & $21.56 \pm 0.08$ & $21.89 \pm 0.07$ & $21.59 \pm 0.08$ \\
\hline Fat, \% & $4.90 \pm 0.02$ & $4.83 \pm 0.05$ & $4.80 \pm 0.04$ & $4.60 \pm 0.04$ \\
\hline Ash, \% & $1.02 \pm 0.02$ & $0.98 \pm 0.02$ & $0.97 \pm 0.03$ & $1.00 \pm 0.03$ \\
\hline Tryptophan, mg & 336.8 & 340.4 & 341.7 & 338.7 \\
\hline Oxyproline,mg & 43.1 & 42.1 & 41.0 & 42.0 \\
\hline PQI & $7.81 \pm 0.06$ & $8.08 \pm 0.04$ & $8.33 \pm 0.05$ & $8.06 \pm 0.07$ \\
\hline
\end{tabular}


It was found that the most positive effect on the productivity and reproductive parameters of sows was provided by soybean additives in a dose of $25 \%$ of the digestible protein rate, which in animals of the $2^{\text {nd }}$ test group ensured a significant $(\mathrm{P}<0.05)$ superiority to the control analogue in the number of litter at birth by $10.0 \%$; the birth weight of the litter of piglets - by $13.76 \%$; milkiness of sows on the $21^{\text {st }}$ day after farrowing - by $10.8 \%$; the weight of piglets at the age of 2 months - by $6.9 \%$ and the live weight gain for 2 months - by $7.2 \%$. In addition, the survival rate of pigs by the time of weaning in the $2^{\text {nd }}$ experimental group of animals was $1.2 \%$ higher than in the control.

After the experiment on sows was completed, four groups of 12 animals each were formed from weaned pigs at the age of 2 months, after that they were transferred to the pig fattening department. A month before slaughter, soybean was excluded from the rations of gilts from experimental groups to increase the consumer qualities of their meat.

In the course of the experiment, the effect of different levels of soybean protein on slaughter characteristics of experimental pigs was studied (Table 5).

It was found that, in comparison with the control group, gilts of the $2^{\text {nd }}$ experimental group had significantly $(\mathrm{P}<0.05)$ better indicators of pre slaughter live weight by $12.02 \mathrm{~kg}$, slaughter weight - by $10.74 \mathrm{~kg}$, slaughter yield by $1.48 \%$, weight of the chilled carcass - by $9.70 \mathrm{~kg}$, carcass yield $-2.14 \%$, and the weight of the posterior third of the carcass side $-1.01 \mathrm{~kg}$.

The area of the "eye of meat" and the length of the carcass of the animals of the 2 experimental group also significantly $(\mathrm{P}<0.05)$ exceeded their analogues from the control group by $2.09 \mathrm{~cm}^{2}$ and $5.21 \mathrm{~cm}$, respectively.

According to the results of the deboning of the side carcasses of experimental animals, it was found that soybean feeding in a dose of $25 \%$ of the rate of the digestible protein had a more favorable effect on the morphological composition of side carcasses of gilts. In this case, the animals of the 2 experimental group had a significant $(\mathrm{P}<0.05)$ greater meat yield - by $2.97 \mathrm{~kg}$ and fat- $1.14 \mathrm{~kg}$ in comparison with the control.

On the basis of this, after the slaughter the chemical composition and biological value of the protein of the long issimusspinal muscle of the experimental animals was studied (Table 6). The results of the chemical analysis of meat samples showed that the samples of the long issimusspinal muscle of the gilts in the $2^{\text {nd }}$ test group had the best characteristics of the chemical composition 6 significantly $(\mathrm{P}<0.05)$ exceeding the control in dry matter content by $0.72 \%$, protein by $0.8 \%$. Along with the quantitative growth of protein in meat, the young pigs of the $2^{\text {nd }}$ test group had the highest protein quality index (PQI) - 8.33 units, which is $6.6 \%(\mathrm{P}<0.05)$ higher than in the control.

In the compared samples, we studied the indicators of water-holding capacity and $\mathrm{pH}$ of meat (Table 7), determined immediately after slaughter, and also after 24-hour exposure.

Animals of the control, 1 and 2 experimental groups, had this index within the limits of the norm, as indicated by the qualitative characteristics of pork. When soybean was fed in a dose of $35 \%$ of the rate of the digestible protein, the $\mathrm{pH}$ of the meat of animals of the 3 experimental group was significantly $(\mathrm{P}<0.05)$ lower than that of the other groups.

According to the data obtained, the meat of the young pigs of the $2^{\text {nd }}$ test group was characterized by the highest level of water retention capacity, significantly ( $\mathrm{P}<0.05)$ exceeding the control analogues by $7.97 \%$. With an increase in the dose of soybean additives up to $35 \%$, this index in the gilts of the 3 experimental groups was significantly $(\mathrm{P}<0.05)$ lower as compared to the animals of the 2 experimental group.

Due to the composition of lipids, soybean products can have a significant effect on the consumer characteristics of meat products of pigs, largely due to the physicochemical properties of fat (Table 8). The most significant effect on the consumer qualities of the pork fat was provided by the consumption of soybean in a dose of $25 \%$ of the rate of the digestible protein. Therefore, as compared to the control, the gilts of the 2 experimental group had larger thickness of the fat by $0.49 \mathrm{~cm}(\mathrm{P}<0.05)$, the dry substance concentration was lower by $0.47 \%$ and the melting point was lower by $2.9^{\circ} \mathrm{C}$. In comparison with the control, in the fat of the gilts of the $2^{\text {nd }}$ experimental group, the concentration of saturated fatty acids was $3.2 \%$ lower and there was an increase in monounsaturated fatty acids by $1.1 \%$ and polyunsaturated - by $2.1 \%$.

Soybean products are deficient in sulfur-containing amino acids; therefore, synthetic methionine was added to methionine+cystine feeding standards for pigs in experimental groups. Due to the optimization of the ratio of lysine to methionine+cystine and methionine to cystine with the help of synthetic methionine additives, by the end of the gestation period, the animals of the 2 experimental group were characterized by better productivity.

In our opinion, the increase in slaughter performance in animals from the $2^{\text {nd }}$ experimental group, that received soybean in a dose of $25 \%$ of the digestible protein rate, was the consequence of optimizing the ratio of essential amino acids and a higher content of lysine when replacing sunflower oil cake with the soy one. In addition, the presence of acidic, neutral and alkaline proteinases in the enzyme preparation of protosubtilin G3x contributed to this. The consumer quality of meat is mainly determined by its chemical composition, which is largely due to the diet balanced by protein.

Along with the quantitative growth of protein in meat, the young pigs of the 2 test group had the highest protein-quality index (PQI). And an increase in the dose of soybean oilcake to $35 \%$ of the rate of the digestible protein contributed to a decrease in protein content of the meat and its biological value. This was due to the improvement in the ratio of essential amino acids to non-essential with the inclusion of soy protein in a dose of $25 \%$, but at higher intakes this ratio was violated. 
Table 7 - Some technological properties of pork

\begin{tabular}{|l|l|l|l|l|}
\hline \multirow{2}{*}{\multicolumn{1}{|c|}{ Index }} & \multicolumn{4}{c|}{ Group } \\
\cline { 2 - 5 } & control & 1 trial & 2 trial & 3 trial \\
\hline Moisture-retaining power, \% & $58.24 \pm 0.10$ & $63.57 \pm 0.12$ & $66.21 \pm 0.14$ & $60.19 \pm 0.19$ \\
\hline $\mathrm{pH}_{1}$ & $5.82 \pm 0.04$ & $5.86 \pm 0.08$ & $5.84 \pm 0.07$ & $5.69 \pm 0.05$ \\
\hline $\mathrm{pH}_{24}$ & $5.64 \pm 0.02$ & $5.68 \pm 0.05$ & $5.62 \pm 0.04$ & $5.45 \pm 0.04$ \\
\hline
\end{tabular}

Table 8 - Physicochemical properties of fat in gilts

\begin{tabular}{|l|l|l|l|l|}
\hline \multirow{2}{*}{ Index } & \multicolumn{4}{|c|}{ Group } \\
\cline { 2 - 5 } & control & 1 trial & 2 trial & 3 trial \\
\hline Fat thickness, cm & $3.24 \pm 0.11$ & $3.66 \pm 0.16$ & $3.83 \pm 0.14$ & $3.76 \pm 0.13$ \\
\hline Water, \% & 7.22 & 7.55 & 7.69 & 7.58 \\
\hline Dry matter, \% & 92.78 & 92.45 & 92.31 & 92.42 \\
\hline Iodine number & 56.92 & 56.87 & 56.69 & 56.84 \\
\hline Melting temperature, C & 43.7 & 42.5 & 41.8 & 42.0 \\
\hline Total fatty acids, \% & 100.0 & 100.0 & 100.0 & 100.0 \\
\hline including : saturated & 53.2 & 51.2 & 50.0 & 50.6 \\
\hline monounsaturated & 36.4 & 37.0 & 37.5 & 37.3 \\
\hline polyunsaturated & 10.4 & 11.8 & 12.5 & 12.1 \\
\hline
\end{tabular}

Conclusion: 1. It was found that the best effect on the economically useful characteristics of sows and young fattening pigs had the feeding of soybean in a dose of $25 \%$ of the rate of the digestible protein in combination with the enzyme preparation of protosubtilin G3x in the dose of $0.03 \%$ of the dry matter rate. This was contributed by an improvement in the ratio of the essential amino acids of lysine to methionine + cystine and methionine to cystine.

2. Feeding of soybeans in a dose of $25 \%$ of the digestible protein rate had the most favorable effect on the chemical composition of meat of the young fattening pigs of 2test group, which was expressed in a significantly larger deposition of the dry matter by $0.72 \%$, protein - by $0.8 \%$, and also in the increase of the protein-quality index - by $6.6 \%(\mathrm{P}<0.05)$ in the long issimusspinal muscle as compared to the control.

\section{References}

1) KastuyevA.Z., Albegova L.Kh., Tedtova V.V., Tsaliyeva L.V., Markaryan B.M. 2007. Povysheniye pishchevoy tsennosti svininy. Myasnaya industriya, 4(S): 42-44.

2) Khamitsayeva E.S., Tsaliyeva L.V., Mamukayev Z.M. 2009. Biologicheskiye resursy molodnyaka sviney pri raznom urovne soyevogo protein $\mathrm{v}$ ratsionakh. Materialy mezhdunarodnoy nauchno-prakticheskoy konferentsii, Innovatsionnyye puti razvitiya zhivotnovodstva. Pos. Nizhniy Arkhyz. S. 197-198.

3) Kononenko S.I., Semenov V.V., Vorsina L.V., Lozovoy V.I. 2014. Sposoby povysheniya myasnoy produktivnosti sviney,Izvestiya Gorskogo gosudarstvennogo agrarnogo universiteta. T. 51. 2 S: 90-94.

4) Mamukayev Z.M. 2007. Effektivnost' raznykh doz soyevogo zhmykha v kormlenii svinomatok. Materialy IV mezhdunarodnoy nauchno-prakticheskoy konferentsii, Potrebitel'skiy rynok: kachestvo i bezopasnost' tovarov i uslug, Orel. S: 158-159.

5) Temirayev R.B., Khamitsayeva E.S., Tedtova V.V., Mamukayev Z.M. 2008. Sposob uluchsheniya kachestva myasa molodnyaka sviney/ Materialy vserossiyskoy nauchno-prakticheskoy konferentsii Agropromyshlennyy kompleks I aktual'nyye problem ekonomiki regionov. Maykop S. 268-269.

6) Temirayev R.B., Khamitsayeva E.S., Ter-Ter'yan N.G., Mamukayev Z.M. 2009. Vliyaniye soyevogo belka v ratsione sviney na kachestvo svininyi izdeliy iz neye / Myasnaya industriya 11: 46-48.

7) Temirayev V.Kh., Khamitsayeva E.S., Savvoyeva Z.V., Mamukhayev Z.M. 2009. Opyt povysheniya kachestva svininy spomoshch'yu kormovykh dobavok/ Sbornik nauchnykh trudov nauchno-prakticheskoy konferentsii Nauchnyye osnovy povysheniya produktivnosti sel'skokhozyaystvennykh zhivotnykh, Krasnodar. Chast' 2: 231-233.

8) Viktorov P.I. 2003. Prakticheskoye rukovodstvo po kormleniyu sel'skokhozyaystvennykh zhivotnykh I ptitsy I tekhnologii zagotovki dobrokachestvennykh kormov. Krasnodar: 557. 